\title{
Csecsemő- és kisgyermeknevelő BA-képzés az AVKF-en: három év tapasztalatai, képzésünk sajátosságai
}

\author{
GyimeSI IldiKó - UdVARVölgyi ZsOlt ANDRÁs
}

Apor Vilmos Katolikus Főiskola

\begin{abstract}
Az írás röviden bemutatja a Váci Egyházmegye fenntartásában lévő Apor Vilmos Katolikus Föiskola csecsemö- és kisgyermeknevelö alapszakját, a 2016 szeptemberében indult képzés sajátosságait, az eddigi oktatási tapasztalatokat. Továbbá felvázolja a specifikumnak számító tárgyakat és a gyakorlati képzésböl leszürhetö tanulságokat. Végezetül Gyimesi Ildikó szakmódszertant oktató tanár fogalmazza meg a bölcsődei nevelö munkáról alkotott hitvallását.
\end{abstract}

Kulcsszavak: Apor Vilmos Katolikus Föiskola, csecsemö- és kisgyermeknevelö alapszak, Vác, bölcsödei nevelö munka, tantárgyak

\section{Bevezetés}

Írásunkban szeretnénk röviden bemutatni az Apor Vilmos Katolikus Főiskola (http://avkf.hu/) csecsemő- és kisgyermeknevelő alapszakját, képzésünk specifikumait, eddigi tapasztalatainkat, illetve a bölcsődei nevelő munkáról alkotott hitvallásunkat.

Elöljáróban szeretnénk leszögezni, hogy intézményünkben az egyházi/hitéleti szakok mellett zömmel ún. világi szakokon folyik képzés. Amellett, hogy intézményünk nyitott a nem katolikus vallású vagy ateista hallgatók elött is, a képzésünkben minden szakon - így a csecsemő- és kisgyermeknevelő BA-szakon is - megjelenik a római katolikus értékek képviselete, közvetítése.

A Budapestről vonattal mindössze fél óra alatt elérhető Vác egyik impozáns épületében, az egykori katolikus papi szemináriumban kapott helyet az Apor Vilmos Katolikus Főiskola. 2004 óta müködik az intézmény ezen a székhelyen, ahol hallgatóink kulturált környezetben, felújított múemlék épületben tanulhatnak Vác egyik legszebb terén, a Székesegyház szomszédságában.

A Főiskola születése azonban nem Vác, hanem Zsámbék nevéhez kötődik. 1977-ben az Esztergomi Tanítóképző Főiskola kihelyezett tagozataként múködött, 1981-ben pedig már az önálló Zsámbéki Tanítóképző Főisko- la jött létre, az ország egyetlen falusi fôiskolájaként. 1993-tól, az egyházi visszavételtől az intézmény neve Zsámbéki Katolikus Tanítóképző Főiskola lett, 2000-ben pedig az iskola felvette Boldog Apor Vilmos vértanúhalált halt püspök nevét. A 2003-as év a zsámbéki működés végét hozta, egy sajnálatos tủzeset miatt a képzés ott nem volt folytatható. 2004ben a Főiskolát átvette a Váci Egyházmegye ordináriusa, és azóta a váci helyszínen folyik a képzés sokkal több szakon, mint a kezdetekben ${ }^{1}$. Jelenleg a csecsemö- és kisgyermeknevelő szakunkon kívül tanító, óvodapedagógus (angol nyelven is), szociálpedagógia, kántor és katekéta-lelkipásztori munkatárs alapszakokon, illetve neveléstudomány, szociálpedagógia és mentálhigiénés közösség- és kapcsolatépítő mesterszakokon folyik képzés intézményünkben².

Főiskolánk egyházi fenntartású felsőoktatási intézmény, jelenlegi fenntartónk a Váci Egyházmegye. Érdekességképpen megjegyezzük, hogy a neves közéleti személyiségnek is tekinthető és köztiszteletnek örvendő Beer Miklós püspök atya 15 évnyi szolgálat

\footnotetext{
${ }^{1}$ Libor Józsefné PhD: Rektori köszöntő in: http://avkf.hu/ index.php/avkf-es-egysegei/rektori-koszonto/ (Utolsó megtekintés: 2019. augusztus 3.)

2 http://avkf.hu/index.php/kepzesek/ (Utolsó megtekintés: 2019. augusztus 4.)
} 
után, 2018-ban nyugdíjazását kérte, és Ferenc pápa 2019. július 12-én Marton Zsolt atyát nevezte ki új váci megyéspüspöknek. A püspökszentelésre 2019. augusztus 24-én került sor a Váci Bazilikában.

Három éve, 2016 szeptemberében kezdődött a váci Apor Vilmos Katolikus Főiskolán a csecsemő- és kisgyermeknevelő alapszakon (BA) a képzés. „Nálunk esélyt kaphatsz, hogy ezer esélyt adhass." -szól a föiskola szlogenje. És ez talán igaz a „csecsemős” hallgatóinkra is. Idén végzett az első BA-s évfolyamunk. Záróvizsgájukon kiválóan szerepeltek, büszkék vagyunk rájuk. Próbáljuk több csatornán, fórumon, felületen (pl. hirdetések, média, nyílt napok, közösségi oldalak, volt hallgatóink és gyakorló intézményeink kapcsolatrendszerei) népszerűsíteni képzéseinket; szakunkat szórólapjainkon így hirdetjük: „Neked ajánljuk, ha,

- leendő szakmádat hivatásnak tekinted, és elkötelezettséget érzel magadban a 0-3 éves gyermekek nevelése iránt,

- a csecsemő- és kisgyermeknevelő tevékenységére felkészítő elméleti és gyakorlati ismeretek igazi szakemberektől szeretnéd elsajátítani,

- biztos, kiszámítható, a pedagógus életpályamodellre épülő karriert, és változatos, sok örömmel járó munkát szeretnél."

\section{Specifikumaink}

A szak mintatanterveit a képzési és kimeneti követelményeknek megfelelően alkottuk meg. A 2019 őszétől érvényes mintatanterveinkben összesen 53 db kurzus szerepel, az elöírt ismeretköröknek megfelelő csoportosításban. Hallgatóink minden félévben - a főiskolai órákon kívül - egyéni és csoportos gyakorlatokra is mennek. Aktív kapcsolatokat ápolunk gyakorló bölcsődéinkkel, Budapest I. VI., X. kerületeiben, illetve Dunakeszin. Mivel a szociális szférában, így a bölcsődékben is egyre nagyobb a munkaerőhiány, hallgatóink sokszor a gyakorlatok ideje alatt már konkrét állásajánlatokat kapnak. Úgy véljük, a legjobban az bizonyítja főiskolánk és a gyakorló bölcsődéink közötti eredményes kapcsolatokat, ha egy hallga- tó - gyakorlati idejét eltöltve a bölcsődében, megismerve a kisgyermeknevelö mentorokat, bölcsődevezetőket - úgy dönt, hogy első munkahelyként is őket választja. (Minden évben több ilyen hallgatónk is van.)

További sajátosságunknak tekinthető, hogy kis és - úgy véljük - családias hangulatú főiskola vagyunk, így személyes kapcsolatban állunk minden egyes hallgatónkkal. Szakfelelősként is és gyakorlati képzéseket koordináló, illetve szakmódszertant oktatóként is minden hallgatónak a rendelkezésére állunk. Nyitva áll az ajtónk, ha hallgatóink tanulmányi vagy esetleg egyéb jellegű problémáikkal keresnek meg bennünket. Vác kisvárosi jellege, egyházi fenntartónk mivolta, történelmi épületeink, budapesti, illetve Pest és Nógrád megyei vonzáskörzetünk mind hozzájárulnak „Aporos” identitásunkhoz.

Bár ismételten hangsúlyozzuk, hogy szakunk világi képzést folytat, és hallgatóinktól semmilyen hitéleti igazodást nem követelünk meg (nem is várhatunk el), de bizonyos kötelező tárgyainknál megjelennek a keresztény értékek, normák. A „Bevezetés a kereszténységbe" címü, vizsgával záruló kurzus kötelező a hallgatóknak minden szakunkon. Az elöadás célja, hogy megismertesse a hallgatókat a kereszténység alapvető gondolataival, tanításaival, a szentírás fó iránymutatásával, valamint a legfontosabb dogmatikai, egyháztörténelmi és liturgikus ismeretekkel. A tantárgy további célja, hogy a hallgatók képesek legyenek eligazodni a keresztény tanítás és kultúra legfontosabb elemeiben, megismerhessék annak alapjait, tájékozottságuk mélyülhessen a keresztény értékekben, a keresztény nevelési módszerek értékátadásának hátterében. E szemlélet hozzájárulhat ahhoz, hogy eredményesebben foglalkozzanak a keresztény értékeket képviselő családok gyermekeivel, valamint a keresztény iskolák oktató-nevelő munkájába hatékonyabban kapcsolódhassanak be. Úgy véljük, hogy nem vallásos hallgatóknak sem válik kárára ezen, - főiskolánk lelkész-oktatói által oktatott - kurzus.

Főiskolánk oktatója Dr. Pécsi Rita neveléskutató, főiskolai docens, akinek órái minden szakunkon nagyon népszerüek hallgatóink 
körében. Az országosan ismert kolléga azt vallja, hogy „a nevelés az Élet szolgálata” - és ennek módjait kutatja az önnevelésben, tanárként és pedagógiai kutatóként egyaránt. Mindezt leghitelesebben és legelevenebben Josef Kentenich (a katolikus Schönstatt nevelési és családmozgalom alapítója) organikus pedagógiájában találta meg. 1991 óta tartozik a Schönstatt családmozgalomhoz. Neveléskutatóként a személyiség hatékony fejlesztése, az érzelmi intelligencia humán tőkévé alakítása érdekelte. Legjobban tehát az, hogy hogyan tanítsunk-neveljünk úgy, hogy ne csupán ismereteket, hanem életet alakító tudást és tapasztalatot adjunk át. Ezt a pedagógiát tanította a Debreceni Tudományegyetemen, a Károli Gáspár Református Egyetememen, a Széchenyi István Egyetemen, és jelenleg föiskolánk docenseként. A Váci Egyházmegye 27 oktatási intézményében pedagógiai igazgatóként segíti, hogy ezek a pedagógiai tartalmak megújíthassák az iskolák és óvodák életét ${ }^{3}$.

Szakunkon két kötelező tárgya van: Elsőéves hallgatóink a „Bizalom és kötődés pedagógiája" kurzus során megismerik a keresztény organikus bizalompedagógia és kötődéspedagógia alapjait, a csecsemőkor ehhez kapcsolódó legfontosabb nevelési lehetőségeit és a kötődések létrejöttének mechanizmusát. Áttekintik azokat a pedagógiai eszközöket, amelyek az ősbizalom kialakulásában meghatározók lehetnek. A játékfejlődés szakaszainak megismerésével, a zene, a ritmus, az énekes játékok, mondókák pedagógiai hatékonyságát megismerve kialakíthatják és a szülőkkel való kapcsolattartásban a családoknak is segíthetik megteremteni azt a nevelési légkört, amelyben ezek a készségek megalapozhatók.

Másodéves hallgatóink az „Érzelmi intelligencia fejlesztése" c. kurzusát végzik el. Ezen tantárgy központi témája az érzelmi intelligencia fejlesztése fóként a kisgyermekkori lehetőségekre fókuszálva. Az érzelmek idegrendszeri lokalizációja, az értelem és az érzelem intelligenciájának eltérő fejleszté-

\footnotetext{
3 Bemutatkozás in: http://pecsirita.hu/bemutatkozas (Letöltés ideje: 2019. július 22.)
}

si módjai, az érzelmi intelligencia készségei, a jobb agyfélteke speciális funkciói alkotják a tartalom gerincét. Lényeges szerepet kap a folyamatban a társas intelligencia, a nevelő kulcsszerepe, és a mese, játék, művészet, érintés, mozgás eszközfunkciói.

Sok szeretettel várjuk és hívjuk a cigány/ roma nemzetiségű hallgatókat is. Úgy véljük, egyre nagyobb szükség van a vonzáskörzetünkbe tartozó bölcsődékben (Pest és Nógrád megye) elhivatott, a legnagyobb hazai kisebbség kultúráját, szokásait, nyelvét ismerő csecsemő- és kisgyermeknevelő szakemberek munkába állására. Minden szakunkon kötelező tárgy, a kiváló romológus kollégánk, Báder Iván által oktatott „Kisebbségtudományi alapismeretek és romológia." A kurzus tisztázza a főbb fogalmakat. Felvázolja a cigányok/romák eredetét, vándorlását és megjelenését a kora középkori Magyarországon, a felvilágosult abszolutizmus romapolitikáját, a romák helyzetét a 19. századi Magyarországon és a 20. század első felében. Továbbá áttekinti a magyarországi cigányok történetét 1945-től, a magyarországi cigányság intézményesülését a rendszerváltás után, illetve a magyarországi cigányság társadalmi problémáit. Különös hangsúlyt fektet a cigány gyerekek iskoláztatásának főbb problémáira, az iskolai szegregációra, az integrációs törekvésekre az oktatásában. Végezetül kitekintést tesz a cigányzene világára, a cigányság táncmüvészetére, képzőművészetére és irodalmára, továbbá a roma jogvédelemre, a cigányokra a médiában, a cigány nyelv sajátosságaira és az európai roma stratégiai programra. Nagyon érdekes és értékes kurzusnak tartjuk ezt a tárgyat is.

További sajátosságként megemlíthető a $D r$. Baksa Brigitta néprajztudós, főiskolai tanár által oktatott „Személyiségfejlesztés a hagyományismeret eszközeivel" c. tárgy is. A gyakorlatorientált kurzus a Kárpát-medence és Moldva néprajzi alapismereteit, a néprajzi tájak, etnikai csoportok néhány jellegzetességét (Dunántúl, Felvidék, Alföld, Erdély és Moldva) taglalja. Majd a nagy- és kiscsalád felépítését, a társas munkák, a munkaalkalmak, a közösségi alkalmak népszokásait, az átmeneti 
rítusokat és szerepüket a családban és a közösségben. Továbbá - többek közt - a születés és a keresztelő szokásait, a gyermekjátékokat, a gyermekfolklórt és a kisgyermekek szerepét a jeles napi, ünnepi szokásokban. A kurzuson nagy hangsúlyt fektetnek az ún. jeles napokra, ünnepi szokásokra az egyházi év rendjében (a karácsonyi ünnepkör köszöntő, színjátékszerü szokásai; farsangi és iskolába toborzó szokások; nagyböjt, böjti játékok, a húsvéti ünnepkör hagyományai; májusfaállítás, pünkösd, pünkösdi népszokások; a nyári napforduló ünnepe, Szent Iván napja, nyári jeles napok; őszi jeles napok, munkaalkalmakhoz kapcsolódó társas munkák, közösségi ünnepek.).

Bár nem tekinthető sajátosságnak, más képzési helyek és szakok kurzuskínálatában is megjelenik hasonló tárgy, de a szakfelelös által oktatott „Pedagóguspálya és munkaeröpiaci ismeretek” c. kurzust több szempontból is hasznosnak véljük. Egyrészt elsőéves nappali tagozatos hallgatóinknál pótolja a középiskolai képzés bizonyos hiányosságait: Érettségizett hallgatóink bekerülnek úgy a felsőoktatásba, hogy sokan alapfokú munkaügyi, pénzügyi, gazdasági ismeretekkel sem rendelkeznek. Ezért az első órákon áttekintjük pl. a bruttó és nettó bér közötti különbséget, továbbá a fóbb adónemeket (SZJA, ÁFA stb.), a kamat, hitel, deviza, árfolyam, fizetés, jövedelem, közteherviselés, költségvetés, munka, munkanélküliség, nyugdíj, társadalombiztosítás fogalmait, a szociális ellátások és juttatások fajtáit (különös tekintettel a családtámogatási ellátásokra). Másrészt a kurzus során a hallgatók elsajátítják a jogi alapfogalmakkal, a jogalkotó szervekkel, és a jogforrások fajtáival kapcsolatos legfontosabb ismereteket, valamint megismerik a központi és a helyi közigazgatás rendszerét és szerveit. Továbbá a hallgatók betekintést nyernek a csecsemöés kisgyermeknevelői tevékenység jogi és közigazgatási kereteibe és a szakmai adminisztrációs teendőkbe. Megismerkednek a bölcsődei-óvodai ellátás mai helyzetével, a pedagógus szakma presztízsét meghatározó társadalmi folyamatokkal, a pedagógus életpályamodellel; továbbáa karriertervezés fontosságával és gyakorlati tanácsokat kapnak a munkába állás segítéséhez (álláskeresés, önéletrajzírás, motivációs levél és felvételi beszélgetés technikái). A 2017-től életbe lépett - bölcsődéket érintő - reformokra, a bölcsődeépítési és kapacitásnövelési programokra, illetve a kisgyermeknevelőket is érintő további jogszabályváltozásokra is nagy hangsúlyt fektet a kurzus.

\section{A bölcsődei nevelő munkáról alkotott hitvallásunk}

Gyimesi lldikó szakmódszertant oktató tanár, több kötelező tantárgy felelőse és hallgatóink mentortanára így foglalta össze gondolatait a bölcsődei nevelö munkáról:

Ha a bölcsődei nevelő munkáról, egyáltalán a nevelésről kérdezném az anyákat, apákat, nagymamákat, fiatalokat, mindannyiunknak van tapasztalaton alapuló véleménye, mindannyian kompetensnek érezhetjük magunkat, mint gyakorló szülők, hosszú évek nevelési tapasztalatával rendelkezünk. Ha az utca emberét kérdezzük, szinte mindenki valamilyen választ tud adni arra a kérdésre, hogy mi a nevelés, és saját tapasztalata alapján általánosan meg is tudja fogalmazni. De mégis, mitől szakember a szakember, mitől NEVELÖ?

Sok fontos dolog van a nevelésben, de én most az egyik talán leglényegesebb magját szeretném megvilágítani, a nevelés alanyainak oldaláról. Miért olyan fontos a nevelő személye, személyisége a kisgyermeknevelésben? De általánosságban véve a szociális (szociális mint társadalomért, másokért, más emberekért végzett) munkában? Mit jelent a személyesség? Mit jelent az, hogy személyek vagyunk? Mi a nevelés? A nevelés egyidős az emberiséggel. Az azóta felhalmozódott tudományos és tapasztalati tudás birtokában vagyunk most itt a 21. században. Ezzel a tudással kell a szakembernek választ keresnie a mai kor nevelési kérdéseire. A múltból merítünk, a jelenben teszünk, élünk, és a jövő felé nézünk, a jövőnek nevelünk!

Értelmezhetjük sokféle nézőpontból, végtelenül leegyszerűsítve a nevelés olyan jellegű 
Csecsemő- és kisgyermeknevelő BA-képzés az AVKF-en...

tevékenység, amelynek a lényege, hogy a nevelő hasson a neveltre. Segítse, lehetőségeket tárjon elé. A nevelésnek van célja, valami felé irányul. Bábosik István professzor nevelési célmodellje a konstruktív életvezetés, mely értékként jelenik meg. A társadalom számára hasznos és az egyén számára aktív, sikeres. Nevelési gyakorlatában kulcsfontosságú a tevékenységek megszervezése, melyben a nevelő irányító szerepet kap. Nem közvetlen személyiségformálás útján sajátíthatóak el, adhatóak át, hanem indirekt módon, példamutatással, hiteles, őszinte emberként való élettel. Az őszinteség, a valódiság, az igaz értéke jelen van a nevelésben.

A nevelői tevékenység értékek átadása, értékek közvetítése, értékteremtés. Milyen értékeket akarunk vagy tudunk közvetíteni? Amelyek bennünk is megvannak. Olyan egyetemes megkérdőjelezhetetlen értékek vannak bennünk, amelyek létüknél fogva értékesek. Ilyen pl. a

- jóság, az erkölcsiség,

- a szépség, az esztétikai élmények és érzések,

- az igazság értéke, mert valódi érzelmekre van szükség minden egyes gyermekkel, minden emberrel kapcsolatban,

- $\quad$ az élet értéke. Minden élet érték. Derűs harmonikus légkört csak valóban derüs emberek tudnak kialakítani,

- az emberi lét értéke. Soha nem volt, soha nem lesz még egy ugyan olyan ember, aki itt ül, aki otthon vár bennünket, akivel együtt vagyunk munkánk során. Egyedi, megismételhetetlen, szellemi lény.

- a megértés akarása,

- a megbocsátás akár másoknak akár önmagunknak,

- a türelem,

- a szeretet. A szeretetben gyökerező kapcsolat a nevelő, segítő munka magja! Ez egy pozitív attitűd, hozzáállás. Ebben a munkában nem lehet színészkedni, nem lehet kedveskedni úgy, hogy nincs mögötte szeretet. A szeretet, a kötődés és a megismerés által nyer értéket. Időt és energiát fektetünk abba, hogy megismerjük a másikat, akár gyermek, akár felnőtt. „Az teszi a rózsámat olyan különlegessé, fontossá hogy gondoztam, ápoltam, védelmeztem, nem csak egy rózsa, hanem az én rózsám."

- az emberhez hozzátartozik a méltósága. Ez egy alapvető emberi érték. Akkor is megvan, ha kiszolgáltatott egy helyzetben.

Ezek az értékek megvannak bennünk, itt és most, ahogy megvannak a másikban is. A gyermekben is, a családokban is, az idősekben, betegekben, elesettekben, még akkor is, ha oly kevéssé látjuk vagy érezzük.

Meg kell látni ezeket az értékeket, észre kell venni, és tudni kell ezeket mások számára is láthatóvá tenni. Többek közt ennek a tudása és folyamatos fejlesztése az, ami a szakembert a laikus nevelőtől megkülönbözteti. Ez a laikus nevelő számára lehetőség, a szakember számára kötelesség és felelősség!

A mai kor leginkább az empíriára hagyatkozik, nagy mintát vesz, átlagokat számol, általánosít, számszerűsített értékeket határoz meg. IQ-, EQ-tesztek, mátrixok, osztályzatok... Mi van ezek mögött? Hol van az emberi lényeg? Hol a nevelés lényege? Mérhető? Számszerűsíthető? Lehet ezt mérni valahogy? Az a súlytábla, amin rajta van számszerüsítve, hogy az emberi test milyen tömegü és hány centiméter magas, azt is meg tudjuk nézni mennyi idő alatt érte el ezeket az értékeket? Meg tudjuk állapítani, hogy milyen szakaszban van a pszichés fejlődése, mit tud már, milyen fejlődési mutatói vannak? Hogyan viselkedik? Ez volna az ember? Mit jelent az, hogy személyek vagyunk? Mit jelent a személyesség? Ennél az ember több!Ezek az értékek nem mérhetőek az empirikus kutatás módszereivel. Mégis, honnan tudjuk pl., hogy szeretnek bennünket? Érezzük. Megérzéseinkre hagyatkozunk, intuícióinkra, lelkiismeretünkre. A lelkiismeret nagyon fontos "érzékszerv".

A nevelö, a gondozó, a segítő szakma elhivatottja a személyiségével nevel, a személyiségét adja akkor, amikor jelen van a gondozottal, a klienssel való kapcsolatban. Mit jelent ez a személyesség? A személyesség a nevelő oldaláról és a nevelt oldaláról is ugyanúgy jelen van. Az ember nem csupán fizikai test, nem 
kizárólag pszichikuma van, hanem szellemisége, egyénisége is. Az ember egység, amely nem felosztható, nem tagolható részekre. Nem lehet összerakni részekből sem, teljesség és egészlegesség. Az egész személy maga több mint a részek összessége. Abszolút új létező. Soha nem volt és soha nem lesz még egy olyan személy. A szülők adhatnak géneket, tulajdonságokat, de lelket nem lehelnek gyermekükbe, nem a személyüket örökítik át, nem a szülőkből vesz el a gyermek azáltal, hogy lesz. „Az épitökövek átültethetőek, de az épitömester nem".

A személy értelmes életet élő, a saját sorsáról gondolkodó és döntést hozó lény, mely a szabadságában mutatkozik meg. Minden pillanatban ott van az ember számára a lehetőség, hogy felelősséggel döntsön saját sorsa felől, hogy gondolkodjon a saját életéről. Az állat a környezetéhez alkalmazkodik, az ember - többnyire - megteremti, megváltoztatja a környezetét.

Az ember ÉN-szerü. Az én tudat kialakulásának a szenzitív periódusa pont a bölcsődés korban alakul ki. Másfél-, két és fél éves korban kezdődik a más személytől való elkülönülés, az Én megtapasztalása és határainak kipróbálása.

Az ember társas lény. A gyermek különösen. „Te” nélkül nincs „Én”. Az én tudat kialakulása előtt a gyermek egylényegű az anyával, ebbe az intim kapcsolatba lép be a nevelő és alakítja ki azt a biztonságot adó érzelmi kötődést, amely az ősbizalom megteremtésére és támogatására irányul. Ezen múlik, hogy a gyermekben kialakulnak-e a szociális készségek, hogy hogyan tudunk a gyermek világához közel kerülni. Bízik-e majd a felnőttekben, a szüleiben, a világban? Ezért a bölcsődei nevelöknek tudatosan kell gondolkodni.

A személynek dinamikája van. Mindanynyian megtapasztaltuk már saját lelki és szellemi erőinket, amikor egy cél érdekében mozgósítjuk a testünket, szenvedünk, küzdünk, és nem adjuk fel. Micsoda lelki erő az, amikor az anya küzd a könnyeivel a bölcsőde előtt. A gyermek leküzdi ragaszkodását, szorítja az otthonról hozott mackóját és besétál az ajtón. A segítő munkában értelmet és célt ta- láló ember számára nem teher a napi feladat, a gondozott nem válik eszközzé, tárggyá, nem veszti el személyességét. Ha így nézzük az emberképet, ebben az egyediségben nézzük önmagunkat, könnyebb észrevenni saját magunkban és az embertársainkban, vagy a gyermekekben rejlő egyedi embert.

A nevelö és a nevelt egyaránt hatnak egymásra. Ebben a kapcsolatban rejlik a nevelés lényege, az érdemi hatni tudás. Magának a kapcsolatnak a minősége határozza meg a szakmai munka minőségét. Hatni tudás, érték látás és érték átadás, megismerés, elfogadás, csak interperszonális kapcsolatban lehetséges! Nem kevés tehát a feladatunk, a felelősségünk. A hagyományok ma már nem mondják meg, mit kell tennünk, hogyan kell viselkednünk, mint régen, évszázadokon keresztül. Ahhoz, hogy megálljunk a lábunkon, hogy ne a tömegek sodrásában éljünk, stabil értékrend kell, mert ez a kapaszkodó, a biztonság, az alap! Az alapja annak, hogy a gyermekeinket, a gondozottainkat, a klienseinket segítsük abban, hogy konstruktív életvezetésre legyenek képesek, értékes, értelmes legyen számukra az itt és velünk töltött idő. Az a nevelésünk célja, hogy az ember megvalósítsa azt az értelmet, azt a feladatot, amiért született, hogy azzá legyen, amivé lennie kell!

A bölcsődei nevelő munka azért is kitüntetett jelentőségü, mert egész életet meghatározó fejlődési szakaszok követik egymást, sorsszerü személyiségjegyek épülnek be az első években. A gyermekkor megkérdőjelezhetetlenül hatással van a további életre. Nem lehet még egyszer élni a gyermekkort, nem lehet kijavítani, ami megtörtént, az a múlt. Nem most lesz látható a munkánk eredménye vagy kudarca, hanem akár húsz-harmincnegyven év múlva. Korrigálni ugyan lehet, különféle terápiák is vannak, de hosszú és fáradságos az a munka, amely során - egy rossz vagy nem elég jó kezdet után, felismerve a hibákat, hiányosságokat - a személy változtat életén. Ezért kulcsfontosságú, hogy ne kövessünk el hibákat, hogy mindent, amit csak lehet, megtegyünk, megteremtsünk a gyermekek számára. Rajtunk múlik, csakis rajtunk, hogy milyen lehetőségeket biztosítunk, mi- 
lyen példát mutatunk, hogyan élünk és gondolkodunk, milyen személyiségjegyek kapnak megerősítést. Gyermekeink tőlünk tanulnak meg beszélni, a jövő felnőttjeinek most van szükségük példaképekre!

A szakember attól szakember, hogy ezeket az értékeket képes meglátni, képes kinevelni önmagában, képes arra, hogy a saját személyiségén keresztül mindezeket átadja. A szakember képes arra, hogy megküzdjön azért a tudásért, hogy segíteni tudjon másokon, segítsen másoknak abban, hogy ők is megtalálják számukra az életben rejlő feladatokat, értelmet. Ez egy holtig tartó elkötelezettség!

\section{Összefoglalás}

Írásunkban röviden összegeztük egy kis, egyházi fenntartású főiskola, újnak számító alapképzésének három éves történetét. Örülünk neki, hogy 2016 őszén elkezdődött és azóta is folyik a csecsemő- és kisgyermeknevelő képzés Vácott. Folyamatosan figyeljük a bölcsődei szféra jelzéseit, reagálunk hallgatóink felvetéseire, megjegyzéseire, azon dolgozunk, hogy hallgatóink gyakorlatorientált, minőségi képzést kapva, korszerű ismeretekkel felvértezve, jól hasznosítható diplomával a kezükben távozzanak főiskolánkról, és visszavárjuk őket mesterképzéseinkre is.

\section{Felhasznált irodalom}

Apor Vilmos Katolikus Föiskola, Csecsemöés kisgyermeknevelö alapképzési szak leírása. http://avkf.hu/index.php/kepzesek/ alapkepzes-ba/csecsemo-ba/

Libor Józsefné PhD: Rektori köszöntő. in: http:// avkf.hu/index.php/avkf-es-egysegei/rektorikoszonto/

Apor Vilmos Katolikus Föiskola, Csecsemö és kisgyermeknevelö alapképzési szak tantárgyleírásai. http://avkf.hu/index.php/kepzesek/ tantargyleirasok2019/\#gorgess

Infant and early childhood education BA training at AVKF: experience of three years, our training

This article briefly introduces the infant and early childhood educator BA program of the Apor Vilmos Catholic College maintained by the Diocese of Vác, the characteristics of the program that began in September 2016, and the educational experiences so far. It also outlines the topics of the specific subjects and the lessons that can be learned from the practical training. Finally, Ildikó Gyimesi, a teacher of technical methodology, formulates her creed on nursery education.

Keywords: Apor Vilmos Catholic College, infant and early childhood educator BA program, Vác, nursery education work, courses 